\title{
Enactments of Curriculum Policies in Greek Secondary Education: Regulative Discourses and the Reproduction of Social Inequalities
}

\author{
Sofia Koutsiouri, Ioulia Antoniou \& Anna Tsatsaroni \\ University of the Peloponnese, GREECE \\ Department of Social and Education Policy
}

Received: 24 July 2021 - Accepted: 23 September 2021 - Published Online: 11 October 2021

\begin{abstract}
Many critical research studies have documented the complex ways in which global policies on school curricula are reshaped at national and local levels. This paper focuses on the discourses which regulate the recontextualizations of global policies in local school settings. The paper presents an empirical study on the enactments of language curricula in the Greek school education system. Using Bernstein's theory of knowledge pedagogization, we analyze data produced by semi-structured interviews and classroom observations in five lower secondary state schools with socially and ethnically diverse student populations, in the inner city of Athens. Our findings show that, while the socially disadvantaged schools are regulated by discourses on inclusion, in the more advantaged schools of the study regulative discourses are related to performance management concerns. The paper points to the potential implications of such discourses, claiming that challenging educational inequalities requires to identify and act upon the discourses regulating teachers' practices.
\end{abstract}

Keywords: regulative discourse, instructional practices, global curriculum policies, Bernstein, educational inequalities.

\section{Introduction}

The critical research literature has documented the diverse ways in which global policies on knowledge and the curriculum are taken up, reshaped at the national level and recontextualized in local school contexts. Much of this research has been motivated by an interest to show what Ball (1993: 16) has called 'second order effects' of a policy, that is changes to 'patterns of social access and opportunity and social justice'. Thus, it has been argued that global policies, by cultivating a performative culture (Ball, 2003) in local contexts, mainly through national systems of students' assessment and teachers' evaluation, shape teachers' local practices in ways that exacerbate educational inequalities (e.g., Lingard \& Sellar, 2013). However, what current policy research has neglected is the question of how the multiple and often contradictory discourses disseminated within the pedagogic field by different actors affect local curricular policy enactments, shaping the conditions of students' differential access to the official school knowledge.

(C) Authors. Terms and conditions of Creative Commons Attribution 4.0 International (CC BY 4.0) apply. Correspondence: Sofia Koutsiouri, University of the Peloponnese, Department of Social and Education Policy, Damaskinou \& Kolokotroni Str. 20100 Corinth, GREECE. Email: koutsiourisofia@gmail.com. 
This paper focuses on the enactments in urban educational settings of the Greek national recontextualization of global curricular policy trends. The uniqueness of the Greek national context, when compared to other European countries, stems, on the one hand, from the distinctive characteristics of its education system, which, despite many supranational pressures and governmental attempts towards restructuring, remains highly centralized in terms of curricula and administrative coordination. This partly reflects the fact that many of the reforms prevalent in other education systems, e.g., outcomes-based student assessment through national testing, have been fiercely resisted for a long time by teachers' unions and other stakeholders. On the other hand, the dire consequences of the long-lasting fiscal crisis, in conjunction with the abrupt transformation of the Greek society from a mono-cultural to a multicultural and ethnically diversified one, has resulted in school conditions that make the work of teachers very challenging.

The paper presents a study on language literacy policy enactments, carried out in socially and ethnically diverse school settings in the Athens inner city. It utilizes the conceptual tools offered by Bernstein's theory, which help to describe the processes of knowledge pedagogization and their social reproduction or change implications. In particular, using his distinction between the instructional and the regulative components of pedagogic discourse, the study explores how language curricula are recontextualized in these local contexts, what affects such recontextualizations, how teachers shape their pedagogic practices and what their potential effects are on students' learning and their social positioning.

In what follows, Section 2 refers briefly to the global curricular policy trends shaping the educational landscapes worldwide, while Section 3 describes the distinctive features of the Greek national policy context. Sections 4 and 5 discuss the concepts of Bernstein's theory guiding our empirical research and our methodology, while Sections 6 and 7 present and discuss the data analysis and findings of the research study.

\section{Global policies on school curricula and language education}

Over the last decades, supranational and international agents (OECD, EU, UNESCO) have persistently promoted policies on knowledge, skills and key competencies worldwide, on the argument that they are crucial means for meeting economic and societal challenges of knowledgebased societies, namely strengthening national competitiveness and growth, and meeting the goals of active citizenship, personal fulfillment and well-being (e.g., European Commission, 2019; OECD, 2018; Official Journal of the European Union, 2006). However, as critical policy studies researchers point out, this globalized agenda on knowledge is fraught with tensions and contradictions. For example, the OECD has traditionally adopted a more 'applied and operational orientation' to knowledge by putting emphasis on skills and key-competencies (Tahirsylaj \& Sundberg, 2020: 143). However, its recently developed framework 'The OECD Learning Compass 2030' focuses on disciplinary curriculum knowledge, although 'imagined [...] in a narrow, utilitarian way' (Hughson \& Wood, 2020: 17). Likewise, the European policies promote disciplinebased knowledge alongside skills and competencies cultivated across the curriculum (Official Journal of the European Union, 2006). These tensions can be traced across and within national policy contexts, as in some countries (e.g., in Sweden and in England), a 'neoconservative' return to discipline-based knowledge has been identified (Anderson-Levitt \& Gardinier, 2021; Nordin \& Sundberg, 2016), framed by regimes of managerial accountability and performativity (Ball, 2003).

However, despite this somewhat renewed emphasis on disciplinary knowledge identified in some contexts, many national systems have taken a 'curricular turn' towards 21st century competencies (Alvunger, Soini, Philippou \& Priestley, 2021; Anderson-Levitt \& Gardinier, 2021; Tahirsylaj \& Sundberg, 2020). This approach to curriculum content is accompanied by a specific view on pedagogy, which includes a learner-centered orientation, active forms of learning, and a view of teachers as facilitators of learning (e.g., Alvunger et al., 2021). Furthermore, such 
curricular changes have been accompanied by neoliberal modes of educational (de)regulation (decentralization, marketization, managerial accountability) and the intrusion of new actors in the educational field (e.g., EdTech Companies) (Ball, 2007).

Regarding language education/language literacy, different policies have been promoted by various global agencies. From the perspective of the human capital theory, OECD's 'Programme for International Student Assessment' (PISA), requires language skills oriented to problem solving and the needs of everyday, 'real' life (OECD, 2019). In contrast, UNESCO, from a more humanitarian point of view, considers language education as a fundamental human right and, more recently, as a resource for achieving equality, social inclusion and multiculturalism (UNESCO \& UNICEF, 2013). Differences in emphasis regarding language education can also be traced in official documents produced at different points in time by agencies in the European Union. The official texts, 'communication in the mother tongue' (Official Journal of the European Union, 2006) and 'literacy' (European Commission, 2019), refer to communication in specific situations and to the critical awareness of the social consequences of the use of language. In 2016, literacy was declared as European citizens' right, under the umbrella of democracy, equality and interculturalism (Council of Europe, 2016). This indicates that the European policies are evolving, drawing selectively on the OECD, the UNESCO as well as other sources.

\section{The Greek political and policy context}

\subsection{Policies for modernizing and Europeanizing the Greek education system}

Since the 1990s, Europeanization and modernization have been the two "narratives with regard to education welfare in Greece' (Zambeta, 2019: 378). Endeavors to modernize the education system and to align it with the European policies have led to the spreading of a new educational culture, emphasizing efficiency, effectiveness and quality as well as ideas related to the principles of New Public Management (Sifakakis, Tsatsaroni, Sarakinioti \& Kourou, 2016).

A radical political program of educational reforms with direct reference to policies promoted by the EU was attempted by a socialist government in 2009 through a series of measures introduced under the banner 'New school: The student first' (Ministry of Education, 2009). The program sought to introduce changes both at the level of school administration (decentralization, school autonomy), and at the level of knowledge and learning (piloting new curricula for compulsory education, digitalization of textbooks and other teaching/learning materials, emphasis on student-centered pedagogies). This program was interrupted with the change of government in 2011 and the political instability that followed, caused by the protracted fiscal crisis. Subsequent attempts to introduce reforms (e.g., national testing, teacher and school (self-) evaluation, in that turbulent political time, were reduced to a patchwork of short-lived policy initiatives, as they met the strong resistance of educational communities, and often criticism from the media and the public. Since 2019, the right-wing party in Office has promoted its agenda of reforms, focusing once again on national testing, cultivation of skills for life, school and teacher (self-) evaluation, and school autonomy (Law 4692/2020).

However, the lack of continuity in policy formation and implementation should not be taken to mean that there are no significant transformations going on in schools and the education field. As documented in a recent study (Sifakakis et al., 2016), the global/European trends towards managerial accountability and performance-based control have penetrated the Greek education administration field, attempting to silence, co-opt or replace alternative and progressive discourses on schools and education. In particular, this study has pointed to the proliferation of pedagogic discourses and linked them to the multiplication of sites 'pedagogizing' (Singh, 2015) the educational professionals with 'principles from other fields', which 'tend to colonize and to redefine education values and purposes' (Sifakakis et al., 2016: 59). Therefore, it could be argued 
that these processes have affected a gradual 'reculturing' of the Greek education field, also identified in other southern European countries with similar responses to European policies (Grimaldi \& Serpieri, 2013).

It is also important to note that despite these on-going transformations, the Greek education system retains many of its old features. Education as a public good, guaranteed by the state, is regulated by hierarchical structures and relations and coordinated by bureaucratic rules. This means centralized human and financial resources allocation, centralized curricula, and high levels of 'professional autonomy' for head teachers and teachers, within their 'professional space' (Jones et al., 2008, in Hall et al., 2015: 495).

\subsection{Curricular policies}

The specificities of policy-making in Greece, exacerbated by the socio-economic and political context, as described above, have affected the ways curriculum policies have developed over the last decade. Since the 2000s, global policies on literacy - the focus of our research in this paper - have penetrated the Greek education through two curricular reforms for compulsory education (in 2003 and 2011). The two curricular programs have recontextualized dominant discourses on language teaching, by placing emphasis on the development of general communication skills alongside other 'soft' skills (critical thinking, digital skills, creativity, etc.), deemed appropriate to everyday life and to contemporary knowledge-based societies (Pedagogic Institute, 2003, 2011). The more recent curriculum of 2011 is orientated more explicitly to the principles of lifelong learning, active citizenship, and communicative competence required in the contemporary diverse and fluid world of work and life (Pedagogic Institute, 2011). It also introduces a more learner-centered and outcome-oriented approach to teaching and learning. The two curricula also rearticulate globally promoted principles in curriculum development (interdisciplinarity, experience-based learning) and approaches to language teaching (communicative and genre-based approaches, critical literacy). However, while discursive shifts towards $21^{\text {st }}$ century learners' skills have been gradually made, the language curriculum remains subject-based, raising the question of how teachers negotiate these diverse influences in their classrooms.

\subsection{Discourses on inclusion}

Part of the process of Europeanisation and modernization of the Greek education was a gradual marginalization of discussions on educational (in)equality, prevailing, at least at the level of rhetoric, during the years after the restoration of democracy (1974-1990), and a growing interest about 'social inclusion'. The latter refers to specified social groups (minorities, disabled people, economic immigrants and, more recently, refugees), representing a new category of school population (Lindblad \& Popkewitz, 2002, cited in Zambeta with Kolofousi, 2014). Especially the drastic reduction of (education) welfare provision during the last decade has created spaces for diverse discourses on inclusion to emerge and circulate in the public sphere and the field of education (Kanellopoulos et al., 2020). At the same time, whatever policies were promoted, mainly with the financial support of the EU, tended to be inconsistent and fragmented (Zoniou-Sideri, Deropoulou-Derou, Karagianni \& Spandagou, 2006), while the number of people at risk of social exclusion (immigrant and refugee populations' settlements, poverty and policies of austerity) has increased exponentially. These conditions put pressure on public schools to manage inclusion policies', often with very little support from the government. 
4. Analyzing processes of knowledge pedagogization and curriculum enactments in local settings

The focus of this paper is on the forces regulating the pedagogic practices through which the Greek language curricula are enacted in the classroom. Our approach utilizes Bernstein's conceptual and analytical tools which help describe the principles and the complex processes through which knowledge is pedagogized, captured by the notion of recontextualization (Bernstein, 1990, 2000).

Bernstein's theory describes a set of rules through which knowledge from diverse academic fields is selected and re-organized, in order to be transmitted and acquired in official educational institutions. The process of transferring knowledge from the field of its original production (e.g., universities, research laboratories) to fields described by Bernstein as fields of recontextualization and reproduction (school settings), is not neutral or 'empty' of ideology (Bernstein, 2000). During this process, knowledge passes through 'ideological screens' (Bernstein, 2000: 115), regulated by power and control relations. The field of recontextualization is comprised of two sub-fields: the Official Recontextualizing Field (ORF) (the state and, currently, supranational agencies mediated by the state and/or local educational authorities) and the Pedagogic Recontextualizing Field (PRF) (university departments of education, agencies of all kinds offering teacher development courses, specialized media of education, etc.) (Bernstein, 1990).

Classification and framing are core concepts in Bernstein's theoretical framework for analyzing forms of pedagogic discourse and practice. Classification refers to the degree of insulation between categories of discourse, agents, practices and contexts, providing recognition rules that enable students to produce legitimate texts (Bernstein, 2000). Framing 'refers to the principles regulating the communicative practices of the social relations within the reproduction of discursive resources, that is, between transmitters and acquirers' (Bernstein, 1990: 36).

To analyze the various forms of pedagogic practice through which pedagogic communication is realized, we combine the varying values of classification and framing with the notion of 'orientation to meaning'. The latter can be described 'as the selection and organization of meaning' (Holland, 1981: 1), and it can be context-depended or context-independent. The former leads to a horizontal discourse, that is to local, context-specific forms of knowledge, segmentally organized. The latter takes the form of a coherent, explicit and systematically principled structure of knowledge and leads to a vertical discourse (Bernstein, 2000).

Attention to framing is important because it regulates two systems of rules shaping the pedagogic discourse and its enactments in local settings: (a) the rules of discursive order, which constitute the 'instructional' component of the pedagogic discourse, and refers to the selection, sequence, pacing, and criteria of the knowledge aimed to be transmitted (instructional discourse'); and (b) the rules of social order, which constitute the 'regulative' component of the pedagogic discourse ('regulative discourse'). The latter is a moral discourse that provides the criteria shaping character, conduct, manner, and posture (Bernstein, 2000). It includes the theory of instruction which, always infused with ideological preferences, (in)forms the model of the acquirer and the transmitter and the relation between them, projected by the pedagogic discourse. According to the theory, the instructional discourse is embedded in the regulative discourse, which 'regulates what knowledge is selected and how it is organized to produce selective orientations to meaning' (Singh, Thomas \& Harris, 2013: 469).

The theory starts with the assumption that the regulative discourse regulates the distribution of different forms of knowledge/skills to various social groups, reproducing a given social order. However, the complexity of the processes of knowledge recontextualization recognized by the theory suggests that these processes are much more open and indeterminate. Consequently, the analytical concepts of the theory, crucially for this research the notion of 
regulative discourse, are generative (Moore, 2013), aiming to direct inquiry towards analyzing the social reproduction as well as the transformation and change of social relations in and through education.

In our study we worked with the theoretical assumption that, despite the often invisible state of its principles, the regulative is the dominant discourse, underpinning the visible elements of instructional discourse. Furthermore, as other Bernstein scholars have shown, in the current conditions, globalized discourses, recontextualized in national educational fields, exert strong influence in the regulation of educational professionals' work. For example, Robertson and Sorensen (2018: 471) argue that 'the OECD can be understood as a global actor that has come to dominate the field of symbolic control over what counts as 'the good teacher' and 'quality education'. Such regulative discourses, conveying forms of 'legitimate' professional knowledge and disseminated vertically within the education field, compete with or are reinforced by other discourses circulating horizontally in currently proliferating sites for the 'pedagogization' of teachers (Singh, 2015).

Our research study seeks to identify the regulative discourses that are diffused within the Greek educational field, and how they influence the instructional discourses. As already suggested, Bernstein's conceptual grammar offers productive tools for exploring this research problem.

\section{Research method}

The empirical research was carried out over four school years (2017-2021), in five lower secondary state schools (students' age 12-15). The schools are located in the Athens inner city, an area rapidly restructured by socio-spatial transformations and the fiscal crisis, resulting in increased social and ethnic diversity, poverty and marginalization (Kandylis, Maloutas \& Sayas, 2012).

Two of the schools participating in the research study (hereafter Schools A and B) are located in highly disadvantaged districts of the inner city. In Schools A and B, student populations come almost exclusively from working class backgrounds and are also ethnically diverse, mainly consisting of immigrants (and a small number of refugees and asylum seekers) (85-90\%). Two of the other Schools (hereafter Schools C and D) are located in less disadvantaged districts of the inner city, though these areas cannot be characterized as privileged, as they are inhabited mainly by working class people. Schools C and D have lower rates of immigrant students (20\%) than Schools A and B. However, the majority of their student populations has low socio-economic backgrounds. In all four schools the majority of migrant students were born and grew up in Greece or they have been living in Greece for many years. The fifth school (hereafter School E) is located in a district inhabited mainly by middle class Greek people. Its student population is more privileged in terms of ethnic and class origin, as only 6-7\% of students are immigrants and the rest of them come from families from middle socio-economic and/or middle to high educational backgrounds. As a result, School E can be considered as the most advantaged school of our sample, concerning students' composition and location.

The data has been produced through 28 semi-structured interviews with teachers $(n=21)$, head teachers $(n=5)$ and school advisers $(n=2)$ as well as 20 hours of classroom observations. The main research questions were about teachers' enactment of the language curriculum in the specific school settings, the forms of pedagogic practice shaping the pedagogic interactions in classrooms (instructional discourse) and the ways in which the pedagogic work is regulated (regulative discourse), in the absence of any external visible controls on teachers (see Section 3). 
Our data was analyzed by operationalizing the concepts of Bernstein's theory, referred to in the previous section. Data analysis was also based on 'an empirical typology' of the regulative discourse we have developed in the context of this research, which derived primarily from data but also was informed by the literature on inclusion, social integration and social justice as well as on school knowledge and governance (see Sections $2 \& 3$ and below, Section 6).

\section{Results}

\subsection{The schools' local conditions}

The analysis of the interview dataset has identified significant differences regarding the context in which each of the schools of our sample works. In the more disadvantaged schools, students' material deprivation, ethnic diversity and bilingualism, and often families' lack of knowledge of the Greek education system and/or familiarity with the formal educational code seem to affect negatively students' performance in Modern Greek Language (Bernstein, 1977). In these circumstances, teachers are called upon to meet the needs of a linguistically and culturally heterogeneous and socially disadvantaged student population without substantial support from the government. One of the interviewees describes students' diversity and the demanding conditions under which many inner-city schools work as follows:

Another peculiarity of the inner-city schools is that they are multinational. [...] They have students from different nationalities, they also have Roma children. Some of them have Muslim students too. So [...] they are multicultural, in practice. Another important thing is that students come from socially weaker classes, so they are not supported by parents either educationally or financially. (School Adviser 2)

In contrast, in the more advantaged schools of our sample (especially in School E), students are more familiar with the official educational code and teachers encounter less serious problems in implementing the language curricula. The Head teacher of School E describes students' academic performance and their attitude towards schooling as following:

We aren't rallying for a school of high academic achievers, we have exceptional students, we have average students, we have poor students, like all the other schools in Greece. But these students are very much influenced by the institution of family and by the close-knit family, by family values regarding behavior, and this is reflected in the fact that the school has no incidents related to violent acts or delinquent behaviors. (School E, Head teacher)

\subsection{Regulative and instructional discourse}

Our data analysis shows that the pedagogic practices differ significantly between and within the schools of our sample. In the two more disadvantaged schools (School A and B), a strong regulative discourse on inclusion as the main tenet of modern mass schooling, drawing on diverse discursive resources, is mediating the instructional discourse. In the data from interviews, we have identified three different versions of the inclusion discourse, regulating pedagogic practices (see Tsatsaroni \& Koutsiouri, in press).

The first version incorporates a deficit view of students' cultural and social background, perceives inclusion in terms of assimilation into the dominant culture and society (Barton, 1997), and leads to practices of social control. This approach to inclusion is more obvious in School A, where it seems to be promoted especially by the head teacher in his efforts to change the culture of the school. 
The socialization that takes place here is important. I told you, these kids are learning Greek, they go to Greek school, but they have the mentality that is dominant in their homes. (School A, Head teacher)

The second version of the discourse on inclusion focuses on vulnerable students' emotional support and articulates what other researchers have called a 'therapeutic discourse' (Brunila \& Rossi, 2018). This version, also identified in School A and partly in School C, often leads to changing teachers' practices, as students' 'emotional well-being' becomes a high priority for them (Ecclestone, 2011), often at the expense of students' 'intellectual enhancement' (Bernstein, 2000).

I believe that this school presents a challenge. You are here to fight for the students' benefit, and not educationally speaking. But to make them better people, to offer them emotional support. (School A, Teacher 1)

The first two versions of the discourse on inclusion tend to underpin instructional practices characterized by an emphasis on cultivating basic literacy skills, which make low intellectual demands on students, and often lead to pedagogical interactions that orient students to context-specific meanings (Wheelahan, 2010). On the contrary, advanced literacy skills (e.g., critical thinking) are not aimed at by teachers, as they are considered unlikely to be achieved by students of disadvantaged backgrounds. These versions of the regulative discourse on inclusion, especially the therapeutic one, affect assessment practices in ways that do not enable students to produce 'legitimate' school texts (Bernstein, 2000).

Evaluation is related to the student himself. Circumstances are exceedingly varied; I take them into account. The child himself, how he has developed, whether he has made any progress, great or small. (School A, Teacher 5)

A third version of an inclusion discourse, which regulates some classrooms in the more disadvantaged schools of our sample, draws on 'policies of empowerment' (Power, 2012). This discourse promotes practices that respect difference and encourage students' participation in learning processes. Teachers embracing this discourse value the co-existence of diverse cultures and regard heterogeneity as a catalyst of change in the inner-city areas.

Discourses on recognition of difference are translated by teachers in different ways. Sometimes the dictum of 'hearing' all students' voices does not translate into practices that enable them to produce legitimate school texts; in Bernstein's (1990) terms, to acquire recognition and realization rules. Other times, discourses on empowerment and participation are interpreted in ways that give rise to forms of pedagogic practice which tend to orient students to "vertical discourse' (Bernstein, 2000) - context independent, abstract meanings - which is a precondition for students' intellectual enhancement (Wheelahan, 2010). The extract of a classroom interaction below is illustrative of teacher's strong efforts to orient her students to context independent abstract meanings (to introduce students into the meta-language of Linguistics).

Teacher: Who could - and I'm speaking, here, to this row - what age group would speak and say: 'He assed out in front of those people.' 'My father is touched in the head.'

Students: (Give various responses, laughing.)

Teacher: Tell me some phrases that we would hear from other teenagers.

Students: 'We're screwed.'

Teacher: Language like 'we're screwed' is language that is mainly used by the youth age group. It's called 'sociolect'. That is, the language used by a group of people, an age group, a profession, it has to do with social background and it's called 'sociolect'. (School B, Teacher 1) 
In contrast to inclusion discourses, prevalent in the socially disadvantaged schools, in the more advantaged schools participating in our study (Schools D and E), teachers' pedagogic practices tend to be shaped by discourses on how a 'modern school' should look like, which, as already mentioned, are disseminated globally by supranational actors (Robertson \& Sorensen, 2018). Specifically, our data analysis suggests that these regulative discourses shape schools' pedagogic priorities and curricular and especially extra-curricular activities in particular ways. Thus, teachers, apparently aiming to enrich students' social and cultural capital, put a great deal of energy in creating (or conveying an image of) an active, open to society school, capable of facilitating students' future integration into contemporary globalized societies.

We argue that the regulative discourse on 'modern' forms of schooling, prevailing in the less disadvantaged schools of our sample, is articulated around the imperative of performativity, investing the notions of 'good' teaching and learning or of 'effective' schooling with new meanings (cf., Ball, 2003). Activities of all sorts are at the center of schools D and E (extracurricular activities including visits to museums, galleries and theatres available in the Capital, or participation in European school projects (e.g., in Erasmus plus), underscoring the benefits accrued to students as well as teachers themselves. There is a strong tendency to show how these activities are appreciated by students, their parents and the community surrounding the school, and how their school is differentiated from other schools in the vicinity. Though not openly admitting that this active involvement with the outside world might be motivated by a desire to compete in the education market, interviewees from these two schools do make a point about how their distinctive culture attracts students from middle-class backgrounds. In school D, this discourse on the modern school, with its distinctive, outwards looking culture, incorporates also the idea of excellence. The extract below from the interview with the Head teacher illustrates the effects of this performance-driven regulative discourse on School D.

(Students) go to a school that has awards, that offers activities, that offers extracurricular activities. [...] And, of course, our children stand out in the lessons, as well. [...] An effort is being made to carry out the lesson. We do not waste hours. And it shows. And because it shows, if you go to the Lyceum and ask who the best students are, they will tell you the ones from ... (the name of School D). [...] And that's why, every September, it's a madhouse here. (School D, Head teacher)

However, the performance-driven regulative discourse identified in the two more advantaged schools of our sample has its limits, as the national education policy context affects its up-taking, interactions with existing practices and interpretations. In particular, in the absence of any external pressure on schools in the Greek education context (e.g., school evaluation, national testing), performance is mainly linked to outwards-looking culture, while the meaning attributed by teachers to students' achievement in learning remains largely unaffected. That is to say, there is still a rather traditional approach to teaching and learning, which values discipline knowledge (rather than skills and competencies). Thus, research data from School D reveals that despite the dominance of a performance-driven regulative discourse the instructional practices tend to orient students to 'powerful' language knowledge (Moore, 2013).

In contrast, striving for distinction and social recognition, School E appears to value exteriority (extra-curricular activities, students' trips abroad, e.g., a visit to the European Parliament) over strictly defined curriculum demands. The extract below illustrates well this school's orientations.

My personal view is that school should be open [...] to the world. [...] I want the school to be like a step before society, let's say, which prepares them for the social environment in which they will live. (School E, Teacher 1)

As a result, in School E, the regulative discourse on the 'modern' school also includes specific views on 'innovative' teaching. The latter shapes the instructional discourse in ways that 
put emphasis on enriching students' experiences and developing their social skills. So, teachers' pedagogic practices, often informed by child-centered pedagogies, tend to marginalize discipline language knowledge, orienting students to 'soft' skills and context-specific forms of knowledge.

However, despite the diffusion of these new ideas about 'innovative' teaching methods, identified in Schools D and E, and in some classes in School C, in all schools of the Athens innercity in our sample the traditional pedagogic practices dominate. That is to say, the classification between school knowledge and everyday knowledge/experiences remains strong, with hierarchical relations between teachers and students, and teachers' maintaining strong control over the pedagogic communication (strong framing).

\section{Discussion and conclusions}

Located within the critical education policy literature, our research sought to explore how the curricula for Greek language, which incorporate elements of globally dominant discourses (the cultivation of cognitive and social skills, the value of students' everyday experiences, innovative methods of teaching and learning, etc.), are recontextualized in Greek schools. That is to say, schools operating in an education system which in several, important respects, referred to earlier (see introduction and Section 3), differs from other European education systems.

The five secondary schools selected for our empirical study from different parts of the Athens inner city represent, in a sharply pointed way, cases that allowed us to study how the interactions between the particular institutional characteristics of the Greek education system, shaping the workings of the schools and the local conditions in which schools operate, affect the recontextualizations of the language curriculum. In particular, the apparent similarities among the schools of our sample, related to their being located in the densely populated inner city and, like all schools in the country, recruit students from predetermined catchment areas, are counteracted by significant differences. The differences relate to the specific area schools are located in, and consequently the socio-economic background of the students' families and the differences in the students' ethnic composition. Seeking a deeper understanding of how such differences affect the recontextualizations and enactments of the Greek language curriculum - in other words how schools' and teachers' practices are regulated in the absence of any visible controls exerted upon them - we sought to identify the discourses underpinning their practices.

Our data analyses revealed two dominant regulative discourses: A discourse on inclusion, prevalent in the less socially advantaged schools, and a discourse on outwards-looking, modernized schools, dominating the more socially advantaged schools. The different versions of each of these main discourses are found to be related to the different resources drawn on and articulated in each of the schools researched. Thus, the inclusion discourse tends to shape the schools' priorities around issues of how to integrate or support socially and emotionally their students of low income and/or immigrant background. But in its most politically progressive form this discourse appears to motivate teachers to engage with the pedagogical problem of what strategies and what instructional practices could empower them cognitively and intellectually. The second discourse projects an image of the modern(ized) school as an outwards-looking institution, which takes every opportunity and exploits every resource it can possibly reach, in order to strengthen its students' cultural and social capital, and to develop their skills as future citizens of the global(ized) world. This discourse sharpens schools' and teachers' awareness of what is required from them, namely to demonstrate that they aim at and reach such goals. It appears, however, that the performative principle animating this discourse in other national settings is in the Greek setting truncated. So, in the absence of explicit (standardized) measures, the learning outcomes-related performance is replaced by activity-related one. 
This study raises further questions about the kind of discourses circulating within the field of education and invading the school spaces, where they come from, why they find roots in some schools and not others, how they are legitimized, and what their implications are on the reproduction, challenge or interruption of educational inequalities. While the global discourses on performativity and their role in the reproduction of educational inequalities have been amply documented, there is less research addressing such questions with reference to discourses on inclusion. In the Greek context, a research study (Zoniou-Sideri et al., 2006) as well as experiential evidence indicate that inclusion discourses of various kinds abound, circulating in proliferating sites within and beyond the pedagogic field (e.g., 'teacher development' courses offered by public and private agencies). However, much more research would be needed, and in different national contexts, to corroborate this experiential evidence and to advance knowledge on the questions just posed.

Finally, we would argue that such discourses, proliferating in the wider pedagogic and cultural fields are, above all, discourses on new professionalism (e.g., Beck, 1999), that is what it means today to be a 'good teacher'. Beck and Young (2005), approaching this question through Bernsteinian lens, examined the challenges and changes encountered by different professional occupations (including teachers), asking whether professional identities, as we know them, can be sustained in an era of increasing marketization and managerialism. Also, the research by Singh and her collaborators (e.g., Heimans, Singh \& Barnes, 2020) in Australian socially disadvantaged school contexts has showed how Bernstein's conceptual grammar can be utilized in open-ended analyses to explore the complex ways in which interventional efforts and related discourses might reproduce, challenge or interrupt social reproduction. Our study has demonstrated the importance of the theory in exploring the issues posed and for understanding and acting upon the reproduction of educational inequalities. It suggests that we need to continue this line of research utilizing and further developing Bernstein's conceptual and analytical tools, in order to explore the discourses articulated and disseminated within pedagogical and wider cultural fields regulating the work of schools and teachers' instructional practices in specific local contexts.

\section{Acknowledgements}

This research is co-financed by Greece and the European Union (European Social Fund - ESF) through the Operational Programme "Human Resources Development, Education and Lifelong Learning 2014-2020" in the context of the project "Enactments of Greek Language Curriculum in Public Secondary Schools in Athens. The importance of context' (MIS 5049167).

The authors declare no competing interests.

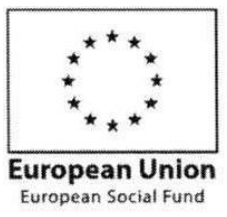

Operational Programme Human Resources Development, Education and Lifelong Learning

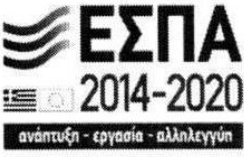

Co-financed by Greece and the European Union 
S. Koutsiouri, I. Antoniou \& A. Tsatsaroni - Enactments of Curriculum Policies in Greek Secondary...

\section{References}

Alvunger, D., Soini, T., Philippou, S., \& Priestley, M. (2021). Conclusions: Patterns and trends in curriculum making in Europe. In M. Priestley, D. Alvunger, S. Philippou. \& T. Soini (Eds.), Curriculum making in Europe: Policy and practice within and across diverse contexts (pp. 273-293). Bingley: Emerald. https://doi.org/10.1108/978-1-83867-735-020211013

Anderson-Levitt, K., \& Gardinier, M. P. (2021). Introduction contextualizing global flows of competencybased education: polysemy, hybridity and silences. Comparative Education, 57(1), 1-18. https://doi.org/10.1080/03050068.2020.1852719

Ball, S. J. (1993). What is policy? Texts, trajectories and toolboxes. The Australian Journal of Education Studies, 13(2), 10-17. https://doi.org/10.1080/0159630930130203

Ball, S. J. (2003). The teacher's soul and the terrors of performativity. Journal of Education Policy, 18(2), 215-228. https://doi.org/10.1080/0268093022000043065

Ball, S. J. (2007). Education Plc: Understanding private sector participation in public sector education. London: Routledge.

Barton, L. (1997). Inclusive education: romantic, subversive or realistic? International Journal of Inclusive Education, 1(3), 231-242. https://doi.org/10.1080/1360311970010301

Beck, J. (1999). Makeover or takeover? The strange death of educational autonomy in neo-liberal England. British Journal of Sociology of Education, 20(2), 223-238. https://doi.org/10.1080/01425699995425

Beck, J., \& Young, M. F. (2005). The assault on the professions and the restructuring of academic and professional identities: a Bernsteinian analysis. British Journal of Sociology of Education, 26(2), 183-197. https://doi.org/10.1080/0142569042000294165

Bernstein, B. (Ed.) (1977). Class, codes and control, Vol. 3. Towards a theory of educational transmissions (second edition) (pp. 37-53). London: Routledge and Kegan Paul.

Bernstein, B. (1990). Class, codes and control, Vol. 4: The structuring of pedagogic discourse. London: Routledge.

Bernstein, B. (2000). Pedagogy, symbolic control and identity. Theory, research, critique (Rev. ed.). New York: Rowman \& Littlefield.

Brunila, K., \& Rossi, L. (2018). Identity politics, the ethos of vulnerability, and education. Educational Philosophy and Theory, 5o(3), 287-298. https://doi.org/10.1080/00131857.2017.1343115

Council of Europe (2016). Competences for democratic culture: Living together as equals in culturally diverse societies. Strasbourg: Council of Europe Publishing.

Ecclestone, K. (2011). Emotionally vulnerable subjects and new inequalities: the educational implications of an 'epistemology of the emotions'. International Studies in Sociology of Education, 21(2), 91113. https://doi.org/10.1080/09620214.2011.575100

European Commission (2019). Key competences for lifelong learning. Luxembourg: Publications Office of the European Union.

Grimaldi, E., \& Serpieri, R. (2013). Privatising education policy-making in Italy: New governance and the reculturing of a welfarist education state. Education Inquiry, 4(3), 442-472. https://doi.org/10.3402/edui.v4i3.22615

Hall, D., Grimaldi, E., Gunter, H. Møller, J., Serpieri, R., \& Skedsmo, G. (2015). Educational reform and modernisation in Europe: The role of national contexts in mediating the new public management. European Educational Research Journal, 14(6), 487-507. https://doi.org/10.1177\%2F1474904115615357 
Heimans, S., Singh, P., \& Barnes, A. (2020). Researching educational disadvantage: Concepts emerging from working in/with an Australian school. Improving Schools, 24(2), 182-192. https://doi.org/10.1177/1365480220938892

Holland, J. (1981). Social class and changes in orientation to meaning. Sociology, 15(1), 1-18. https://doi.org/10.1177/003803858101500101

Hughson, T. A., \& Wood, B. E. (2020). The OECD Learning Compass 2030 and the future of disciplinary learning: a Bernsteinian critique. Journal of Education Policy, 1-21. https://doi.org/10.1080/02680939.2020.1865573

Kandylis, G., Maloutas, T., \& Sayas, J. (2012). Immigration, Inequality and diversity: socio-ethnic hierarchy and spatial organization in Greece, Athens. International Journal of Urban and Regional Research, 19(3), 267-286. https://doi.org/10.1177/0969776412441109

Kanellopoulos, K., Duru, D. N., Zschache, U., Loukakis, A., Kousis, M., \& Trenz, H. J. (2020). Transnational solidarity, migration, and the refugee crisis. In Formal Organising and Political Environments in Greece, Germany, and Denmark. Sociological Research Online. https://doi.org/10.1177/1360780420937030

Law 4692/2020. School Upgrade and other provisions. (in Greek)

Lingard, B., \& Sellar, S. (2013). 'Catalyst Data': Perverse Systemic Effects of Audit and Accountability in Australian Schooling. Journal of Education Policy, 28(5), 634-656. https://doi.org/10.1080/02680939.2012.758815

Ministry of Education (2009). New school: The student first. Athens: Ministry of Education. (in Greek)

Moore, R. (2013). Basil Bernstein: The thinker and the field. London: Routledge. https://doi.org/10.4324/9780203818251

Nordin, A., \& Sundberg, D. (2016). Travelling concepts in national curriculum policy-making: The example of competencies. European Educational Research Journal, 15(3), 314-328. https://doi.org/10.1177/1474904116641697

OECD (2018). The future of Education and skills. Education 2030. Paris: OECD Publishing. https://www.oecd.org/education/2030-project/.

OECD (2019). PISA 2018 assessment and analytical framework, PISA. Paris: OECD Publishing.

Official Journal of the European Union (L 394/10 30.12.2006). RECOMMENDATION OF THE EUROPEAN PARLIAMENT AND OF THE COUNCIL of 18 December 2006 on key competences for lifelong learning (2006/962/EC).

Pedagogic Institute (2003). Interdisciplinary unified context of the curriculum for the Greek Language teaching for gymnasium - The curriculum for the Greek Language for gymnasium. (in Greek)

Pedagogic Institute (2011). The curriculum for Language and Literature Teaching in gymnasium. (in Greek)

Power, S. (2012). From redistribution to recognition to representation: Social injustice and the changing politics of education. Globalisation, Societies and Education, 10(4), 473-492. https://doi.org/10.1080/14767724.2012.735154

Robertson, S. L., \& Sorensen, T. (2018). Global transformations of the state, governance and teachers' labour: Putting Bernstein's conceptual grammar to work. European Educational Research Journal, 17(4), 470-488. https://doi.org/10.1177/1474904117724573

Sifakakis, P., Tsatsaroni, A., Sarakinioti, A., \& Kourou, M. (2016). Governance and knowledge transformations in educational administration: Greek responses to global policies. Journal of Educational Administration and History, 48(1), 35-67. https://doi.org/10.1080/00220620.2015.1040377 
S. Koutsiouri, I. Antoniou \& A. Tsatsaroni - Enactments of Curriculum Policies in Greek Secondary...

Singh, P. (2015). Performativity and pedagogising knowledge: Globalising educational policy formation, dissemination and enactment. Journal of Education Policy, 3O(3), 363-384. https://doi.org/10.1080/02680939.2014.961968

Singh, P., Thomas, S., \& Harris, J. (2013). Recontextualising policy discourses: A Bernsteinian perspective on policy interpretation, translation, enactment. Journal of Education Policy, 28(4), 465-480. http://dx.doi.org/10.1080/02680939.2013.770554

Tahirsylaj, A., \& Sundberg, D. (2020). The unfinished business of defining competences for $21^{\text {st }}$ century curricula - A systematic research review. Curriculum Perspectives, 4O(2), 131-145. https://doi.org/10.1007/s41297-020-00112-6

Tsatsaroni, A., \& Koutsiouri, S. (in press). Global agenda on knowledge and governance, and language literacy practices in secondary education in Greece. In H. Riese, L., Hilt \& G. Soreide (Eds.). Educational standardisation in a complex world. Emerald Publishing.

UNESCO \& UNICEF (2013). Envisioning education in the post-2015 development agenda. Global Thematic Consultation on Education in the Post-2015 Development Agenda.

Wheelahan, L. (2010). The structure of pedagogic discourse as a relay for power: The case of competencybased training. In P. Singh, A. R. Sadovnik \& S. F. Semel (Eds), Toolkits, translation devices and conceptual accounts: Essays on Basil Bernstein's sociology of knowledge (pp. 47-63). New York: Peter Lang.

Zambeta, E. (2019). Technologies of governance and education welfare: monitoring education transitions in Greece. Comparative Education, 55(3), 367-385. https://doi.org/10.1080/03050068.2019.1619331

Zambeta, E., \& with the assistance of Kolofousi, A. (2014). Education and social solidarity in times of crisis: The case of voluntary shadow education in Greece. Education Inquiry, 5(1), 69-88. https://doi.org/10.3402/edui.v5.24058

Zoniou-Sideri, A., Deropoulou-Derou, E., Karagianni, P., \& Spandagou, I. (2006). Inclusive discourse in Greece: strong voices, weak policies. International Journal of Inclusive Education, 10(02-03), 279-291. https://doi.org/10.1080/13603110500256046 